NBSIR 79-1730

\title{
Protecting Adobe Walls from Ground Water
}

James R. Clifton

Frankie Davis

Center for Building Technology

National Engineering Laboratory

National Bureau of Standards

Washington, DC 20234

March 1979

Prepared for

U.S. Department of Interior

-National Park Service

$\rightarrow \cap$ Washington, DC 20240 



\section{PROTECTING ADOBE WALLS FROM GROUND WATER}

James R. Clifton

Frankie Davis

Center for Building Technology National Engineering Laboratory National Bureau of Standards Washington, DC 20234

March 1979

Prepared for

U.S. Department of Interior

National Park Service

Washington, DC 20240

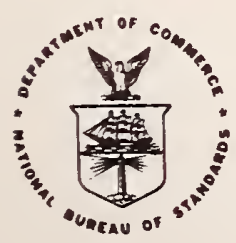

U.S. DEPARTMENT OF COMMERCE, Juanita M. Kreps, Secretary Jordan J. Baruch, Assistant Secretary for Science and Technology NATIONAL BUREAU OF STANDARDS, Ernest Ambler, Director 

ABSTRACT . . . . . . . . . . . . . . . . . •

1. INTRODUCTION . . . . . . . . . . . . . .

2. ADOBE WALLS . . . . . . . . . . . . . . . 1

2.1 Adobe Soils . . . . . . . . . . . . 1

2.2 Adobe Brick . . . . . . . . . . . . 5

2.3 Construction of Test Walls........... 5

3. CAPILLARY RISE OF WATER IN TEST WALLS. • . . . . . . 5

4. PERMEABILITIES OF ADOBE MATERIALS . . . . . . . . . 7

4.1 Measurement of Permeability to Water . . . . . 9

4.2 Results of Permeability Testing ......... 9

5. CHEMICAL GROUTING. . . . . . . . . . . . . 14

6. METALliC DAMP COURSE . . . . . . . . . . . 16

6.1 Test Procedures ............. 16

6.2 Observations. . . . . . . . . . . 17

7. DISCUSSION . . . . . . . . . . . . . . 20

8. SUMMARY AND CONCLUSIONS. . . . . . . . . . . . 22

9. REFERENCES ................... . . . 23 


\section{ABSTRACT}

Two methods for creating impervious membranes in existing adobe walls were investigated. They were the injection of chemical grouts and installation of a metallic membrane. Chemical grouting was unsuccessful because of the low permeability of the tested adobe materials. The metallic membrane did prevent the migration of moisture in the adobe underneath the membrane, weakening the adobe. Further, soluble salts migrated to the surface of the wet adobe. Alternative methods for protecting adobe structures from ground water and runoff water are discussed, including the installation of effective drainage systems and upgrading the foundations.

Keywords: Adobe building materials; chemical grouts; damp course membrane; metallic membrane; permeability; preservation technology. 
The upward migration of ground water in adobe walls is a major factor in the processes by which water erodes and undercuts adobe structures. It can be a serious problem in the preservation of historic adobe structures because often they do not have waterproof foundations or damp course membranes to prevent the rise of water by capillary action. Usually the ground water rises in the walls to above the ground surface to a height which depends on the equilibrium between several factors including the rate of evaporation of moisture from the wall surface. If the ground water has a high salt content, salts may be deposited behind the surface of the adobe wall as the water evaporates. This can result in the undercutting of the wall by spalling of the surface layer [1,2]. In addition, a high moisture content can severely reduce the compressive strength and other mechanical properties of adobe [3].

The purpose of the present study was to determine the feasibility of creating damp course membranes in existing adobe walls by either the injection of chemical grouts or by the insertion of metallic membranes. In addition the effects of creating or inserting an impervious membrane on the stability of existing adobe walls was investigated. Results of this study are given and discussed in this report.

2. ADOBE WALLS

2.1 Adobe Soils

Adobe soils were obtained from Escalante Ruin and Tumacacori National Monument, which are located in Arizona. Escalante Ruin is the remains of the dwellings and other buildings of a prehistoric 
Indian farming community, constructed from earth, located along the Gila River. This site was occupied for several centuries between 900 to $1500 \mathrm{~A} . \mathrm{D}$. The adobe material from Escalante Ruin was taken from the wall of a dwelling unit.

Tumacacori National Monument consists of a mission church, San Jose de Tumacacori, and service buildings. These structures were constructed from adobe under the direction of Franciscan priests in the early 19 th century. The existing buildings at Tumacacori are being preserved in their present condition and adobe samples in the needed amount could not be removed from them. Therefore, test materials, believed to be similar to the materials used by the Franciscans, were taken from the grounds of the site.

The adobe soils were shipped to the facilities of the National Bureau of Standards at Gaithersburg, Maryland, in sealed drums and upon arrival, all of the material from each site was homogenized using a blender. Then the soils were fractionated using a $1 / 4$ inch $(6.35 \mathrm{~mm})$ sieve. The material passing through sieve was used in the preparation of test specimens.

The physical properties (Table 1) of the test materials were measured following the methods given in reference No. 4. The mineralogical compositions of the test materials have been previously reported [5], and are summarized in Table 1. The soil from the Tumacacori area is richer in silt $(26 \%)$ and clay (24\%) than that found in adobe samples from the church at Tumacacori (silt, 8 to 12\%; clay, 8 to 12\%) [5]. Therefore, sand was added to the soil to simulate the adobe in the 
Tumacacori church. Graded sand, meeting the specifications of ASTM C-109 [6] was added to and blended with the Tumacacori soil on an equal weight basis. The silt and clay contents of this mixture were 18 percent and 31 percent, and this mixture is termed "Tumacacori and Sand" in this report. 

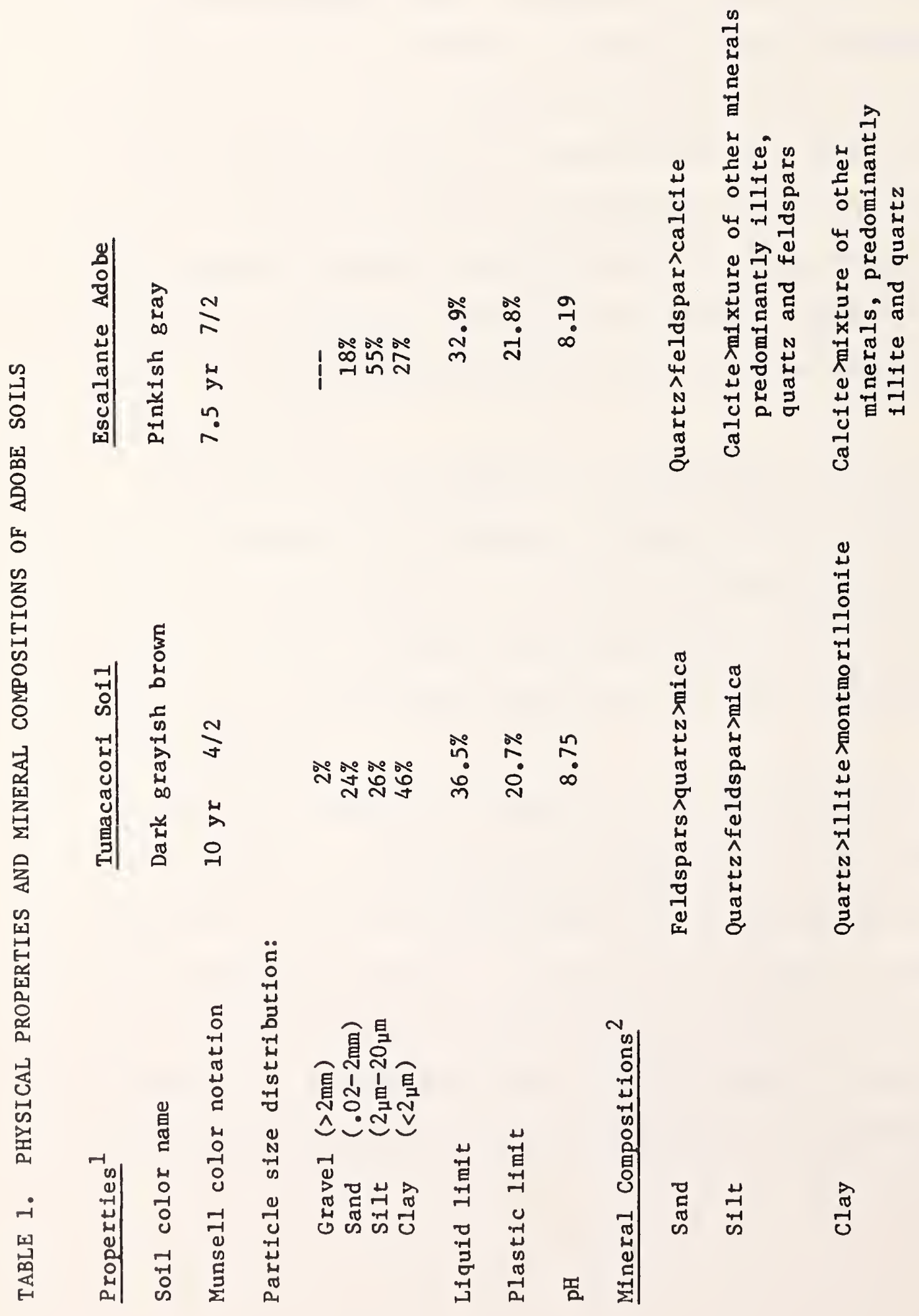

+
$\dot{2}$

Uू

.

$\sum_{01}^{5}$

号

ป

足

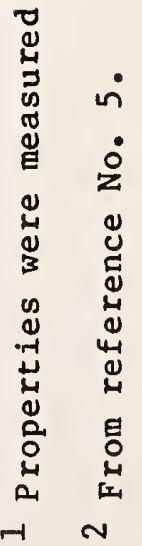


2.2 Adobe Brick

Adobe bricks of dimensions $2 \times 4 \times 8$ in (51 x $102 \times 203 \mathrm{~mm}$ ) were prepared from the adobe soils. The water to soil ratios used in making the bricks were $0.30,0.15$ and 0.25 for Tumacacori soil, Tumacacori and Sand, and Escalante adobe. The soils and water were mixed in a tilting drum mixer having a $1 \mathrm{ft}^{3}\left(.035 \mathrm{~m}^{3}\right)$ capacity, for about 5 minutes. The fresh pastes were placed in wooden molds which had been lightly oiled with 20-30 weight motor oil to facilitate removal of the adobe brick. The bricks were removed from the molds after they appeared to have dried sufficiently to retain their shape. Then the bricks were allowed to dry in laboratory air at $70^{\circ} \mathrm{F}\left(21^{\circ} \mathrm{C}\right)$ and relative humidity near $30 \%$ for an additional month before being used.

\subsection{Construction of Test Wa11s}

Adobe wall sections were constructed using dried adobe brick and fresh mortar having the same composition as the brick. Joints were about $5 / 8$ in $(16 \mathrm{~mm})$ thick. The dimensions of the wall sections were nominal $12 \times 12 \times 10$ in high (305 x $305 \times 254 \mathrm{~mm})$. Test walls were laid on two porous concrete patio blocks ( $8 \times 16 \times 1-1 / 2$ in (203 × $410 \times 38 \mathrm{~mm})$ ) resting in stainless steel rectangular pans. A schematic of a test wall is given in Figure 1. The concrete blocks allowed the upward migration of water while providing a firm base for an adobe test wall.

\section{CAPILLARY RISE OF WATER IN TEST WALLS}

The capillary rise of water into two test walls constructed from Tumacacori and Sand and Escalante adobe brick was measured. Two adjacent vertical faces of each wall were covered with a 0.5 in (13 mm) layer 
of portland cement mortar. The mortar had a composition by weight of 1 part portland cement, 2.75 parts of sand, and a water to cement ratio of 0.45 .

Specimens were removed from the walls after two weeks of testing. Their moisture contents were obtained by drying them to constant weight at $221^{\circ} \mathrm{F}\left(105^{\circ} \mathrm{C}\right)$. The data are listed in Table 2. An analysis of the data indicates that:

(1) The mortar had little effect on the amount of rising water accumulated in the adobe brick immediately above the concrete block.

(2) The moisture content was relatively constant through each brick tier.

(3) Capillary water rose in the Escalante adobe at a much higher rate than in the Tumacacori and Sand brick.

These observations should not be taken to represent the response of an adobe structure to ground water because of the small size of the test wall and the short test period. However, they clearly indicate that a large difference exists in the capillary behavior of the two materials.

\section{PERMEABILITIES OF ADOBE MATERIALS}

The permeabilities of the adobe soils to water were measured to determine if they could be made less permeable to ground water by the injection of chemical grouts. Permeability of a soil is that property which allows the flow of a fluid through it [7]. The permeability of a soll determines if it can be grouted and the type of grout which can be used. 
TABLE 2. AMOUNT OF WATER IN ADOBE TEST WALLS AFTER TWO WEEKS

\section{Moisture Content \\ Percent ${ }^{1}$}

Wall

Material

Tumacacori

and Sand

Escalante

Ado be
1

2

3

4

Brick

Tier

1

2

3

4

4
22

13

8

3

20

21

20

20
18

14

N.M. 4

N.M.

N.M.

22

21

19

17

N.M.

17

1 By weight of dry adobe. The moisture contents of dried adobe bricks prior to making the walls were between 2 to 3 percent.

2 side covered with portland cement mortar.

3 Taken from within one inch $(25.4 \mathrm{~mm})$ of the surface.

4 N.M. indicates moisture contents not measured. 
Permeability of a soil is expressed in terms of the coefficient of permeability $(K)$ by the equation $[7,8]$;

$Q=A K I$

where

$Q$ is the volume of flow per unit time; $K$ is the coefficient of permeability; and I is the hydraulic gradient.

The higher the value of $\mathrm{K}$, greater are the chances of successfully grouting a soil. The permeability of a soil depends on several factors including particle size distribution, porosity, pore size distribution and the mineralogical composition of the soil [7].

\subsection{Measurement of Permeability to Water}

The coefficients of permeability to water of adobe soils were determined by the falling-head permeability test method. This method is similar to the constant-head permeability test described in ASTM D 2434 [9]. In the constant-head method, the quantity of water flowing through a soil specimen is measured for a given time while the head is kept constant. The falling-head test is conducted in the same manner, except that the head of water is not maintained constant but is permitted to fall. The apparatus used for carrying out the falling-head test is shown in Figure 2.

\subsection{Results of Permeability Testing}

No measurable flow of water was collected from the outlet tube of the permeability test apparatus when samples of Tumacacori soil, Tumacacori and Sand and Escalante adobe were tested. The soil specimens slaked and separated as water slowly migrated to the top of the specimens. The slaked soils then appeared to reconsolidate into wet 


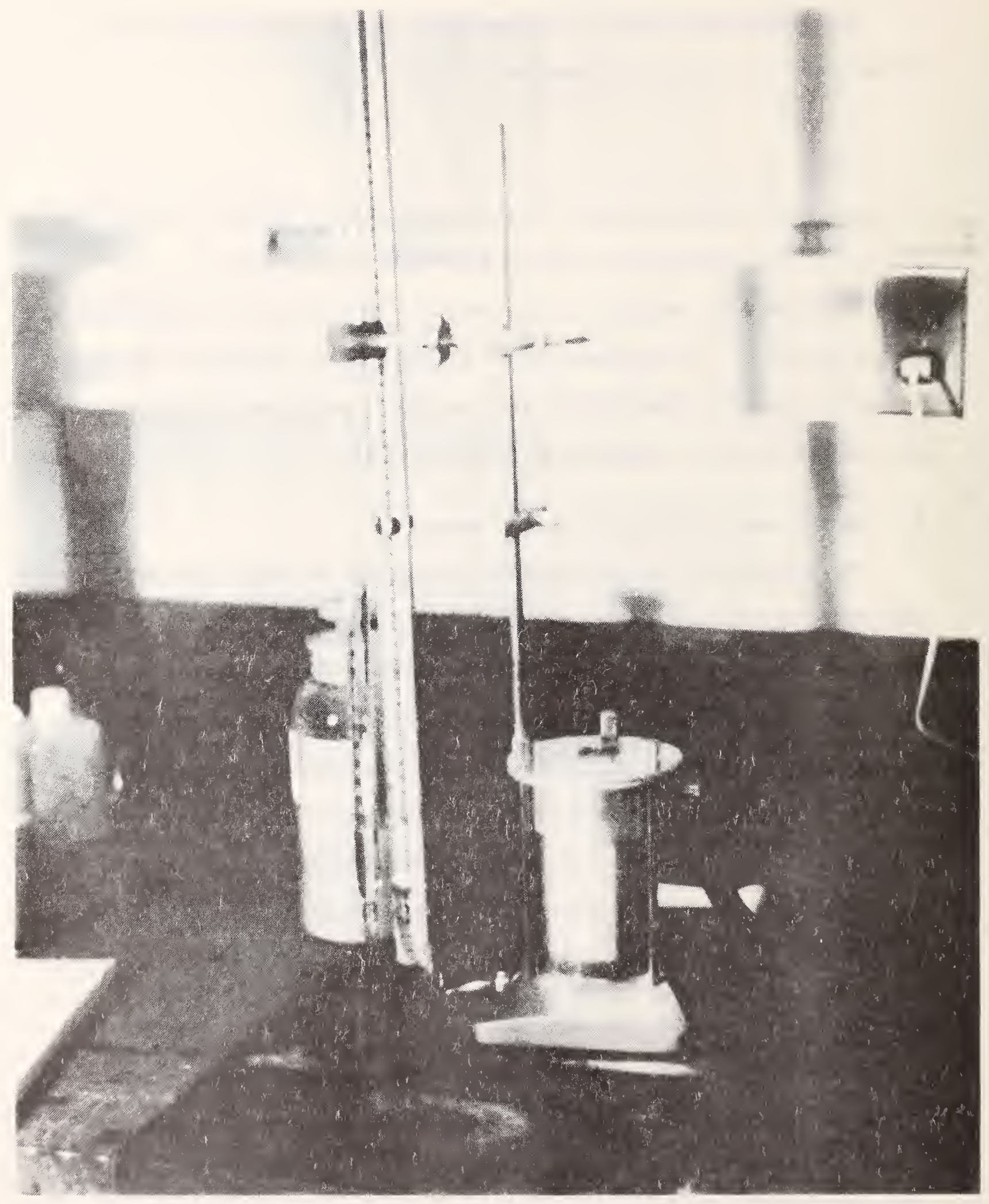

Figure 2. Falling Head Test Apparatus 
masses which were highly resistant to further water flow. The coefficients of permeability for the soils were estimated to be less than $10^{-6} \mathrm{~cm} / \mathrm{sec}$. In general, if the permeability of a soil is less than $10^{-5} \mathrm{~cm} / \mathrm{sec}$, the groutability of that soil is questionable $[7]$

The permeability of a soil also can be estimated if its particle size distribution is known. The relationship between effective particle diameter and the coefficient of permeability is shown in Figure 3. The effective diameter $\left(d_{10}\right)$ is the maximum diameter of the smallest 10 percent, by weight, of the soil particles. Values of $\mathrm{d}_{10}$ were obtained for several materials using the data given in reference No. 5 and are listed in Table 3. Then the $\mathrm{K}$ values for these materials were estimated using Figure 3. Another empirical estimate of the chemical groutability of a soil is that if more than 20 percent, by weight, of its particles pass through a 200 mesh sieve, there is little probability of successfully permeating the soil with any grout [7]. Such data are also presented in Table 3. Note that the estimated values of $\mathrm{K}$ a re below $10^{-6} \mathrm{~cm} / \mathrm{sec}$ for a 11 tested adobes and that more than 20 percent by weight of their particles pass through a 200 mesh sieve. Therefore, it appears unlikely that effective impervious membranes could be created in the tested soils by injecting most types of chemical grouts. 


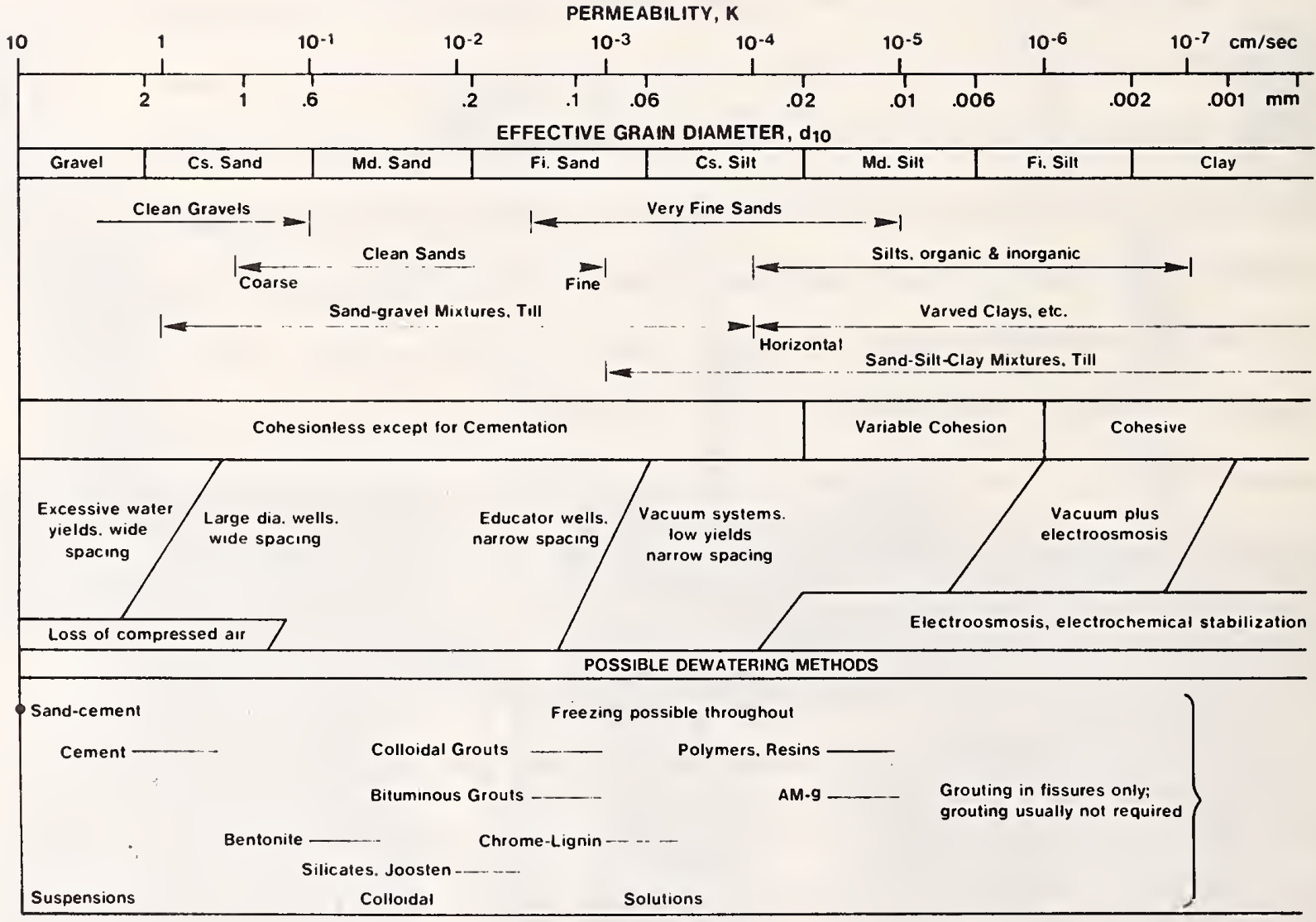

Figure 3. Correlation of Effective Diameter, $d_{10}$, and Permeability [7]. 
TABLE 3. ESTIMATE OF COEFFICIENT OF PERMEABILITY, $K$

Material ${ }^{1}$

Tumacacori Adobe

Tumacacori Soil

Tumacacori and Sand

Escalante Adobe

Fort Bowie Adobe

$$
\mathrm{d}_{\mathrm{mm}} 0^{\underline{2} /}
$$

$>.002$

$>.002$

$>.002$

$>.002$

$>.002$
$\mathrm{K}^{3 / 1}$

$\mathrm{cm} / \mathrm{sec}$

$>10^{-6}$

$>10^{-6}$

$>10^{-6}$

$>10^{-6}$

$>10^{-6}$
Weight Percent Passing Through 200 Mesh Sieve $^{1}$

\section{7}

92

46

52

28

1 Obtained from data in reference No. 5.

2 Maximum diameter of the smallest $10 \%$, by weight, of the soil particles. 3 Estimated using Figure 3. 


\section{CHEMICAL GROUTING}

The types of chemical grouts commonly used for different soils are given in Figure 4. The acrylamide base material appears to be representative of the type of material most capable of penetrating adobe materials with low coefficients of permeability. Therefore, we attempted to grout adobe wall sections and individual adobe bricks with it. In addition, another chemical grout with a formaldehyde base was studied.

A grouting contractor performed the grouting application. Test walls were constructed using brick made from Tumacacori soil, Tumacacori and Sand, and Escalante adobe. Both chemical grouts were injected under pressure into adobe walls at the slowest possible flow rates and at higher rates, with the injection tube being located in the center of the top face. The grouts did not penetrate into the adobe brick but flowed out through small shrinkage cracks in the mortar and started to erode the mortar joints.

In a subsequent study adobe walls and individual adobe bricks were partially immersed in chemical grouts mixtures which had gel times ${ }^{1}$ in excess of 8 hours. The grouts appeared to penetrate the adobe to a depth of less than 1 inch $(25.4 \mathrm{~mm})$. After the grouts had been allowed to harden for 48 hours, water was poured in the steel pans (Figure 1) until the bottom treated portions of the adobe walls were slightly immersed. The water resistance of the treated brick were tested by the same method. Within a few minutes the upward migration of water was observed in both the

1 Time beyond which the viscosity of the mixtures had increased so they would not move in the pores of the soil. 


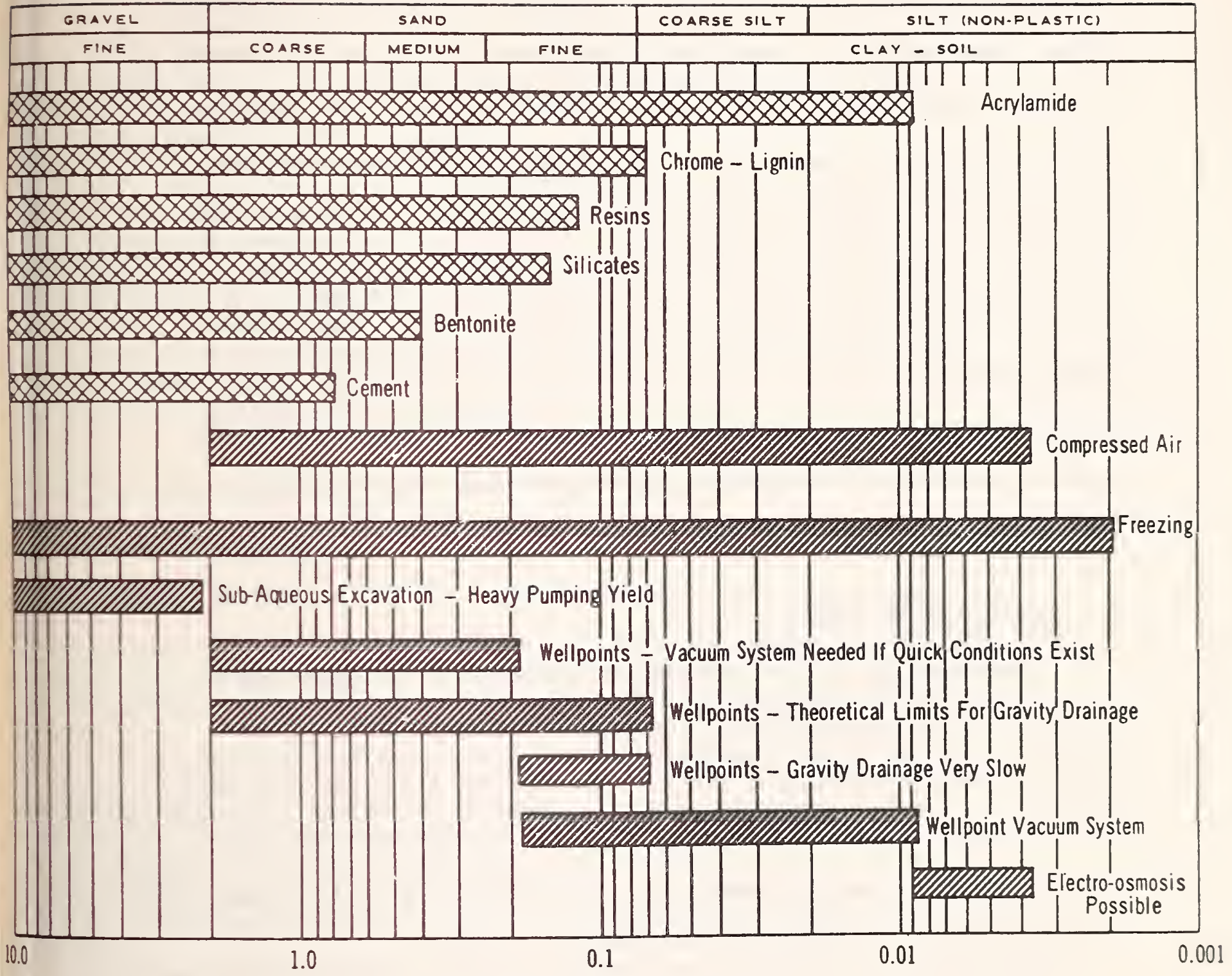

GRAIN SIZE IN MILLIMETERS

Figure 4. Soil Limits for Grout Injectivity $[7,10]$. 
treated walls and bricks, at a rate comparable to the rise in untreated adobe. Examination of treated adobe indicated that the grouting materials were not absorbed by the soils and did not rise in the soils by capillary action. Clearly, it is not likely that the soils tested in this study can be grouted using conventional methods. It is possible that ionic chemical grouts could be made to migrate some distance in these soils under the influence of an applied electrical field, e.g., electrochemical methods. Further work should be carried out to determine if electrochemical methods could be used to sufficiently increase the depth of penetration of chemical grouts into adobe soils so that effective membranes could be formed.

\section{METALLIC DAMP COURSE}

A technique has been developed by Abotomey [11] for inserting a damp course membrane into the walls of an existing building. This technique involves cutting a slot through the fall thickness of a wall and inserting a metal membrane into the slot. The membrane is the same thickness as the slot and on insertion it becomes load bearing, thereby reducing the amount of settlement.

The effect of using a metallic damp course membrane for preventing the upward migration of ground water on the stability of adobe walls was evaluated in the present study.

\subsection{Test Procedures}

A sheet of aluminum metal $1 / 16$ in thick $(1.6 \mathrm{~mm})$ was coated on both sides with epoxy paint to prevent its corrosion. Then it was placed between the first and second tiers (Figure 1) as the adobe walls were 
constructed. Walls were built using Tumacacori and Sand brick. The mortar was allowed to dry for one month. Then water was poured into the steel pans until the concrete patio blocks were immersed to a depth of $3 / 4$ in $(19 \mathrm{~mm})$.

The effect of the water rising to the height of the metallic membrane or the stability of the test walls was determined. The heights of the membrane above the patio block at the four corners of the test walls were periodically measured using a steel ruler with $1 / 32$ inch gradutions $(0.8 \mathrm{~mm})$.

\subsection{Observations}

After a test period of four months it was found that the moisture content of the adobe below the aluminum membrane had increased from about 2 percent to about 20 percent. This was accompanied by a measurable amount of settling in the adobe (Table 4). In addition, soluble salts in the concrete and the adobe brick had migrated within and to the surface of the adobe (Figure 5). As previously mentioned, the deposition of salts behind the surface of adobe walls can result in spalling of surface layers. These observations suggest that placing an impermeable membrane (whether metallic or other) above the foundation in an adobe structure can result in the settling and weakening of the adobe below the membrane. When an ample supply of ground water is sufficiently close to the ground surface to readily migrate up the walls, e.g., Tumacacori church, the value of such a damp course membrane is questionable. 
TABLE 4. SETTLING OF ADOBE TEST WALLS WITH ALUMINUM MEMBRANE

Wa11

No.

Time

14 Months

1 Measured at the four corners of the test walls (Figure 5)
Change in Height Between

Membrane and Patio Block 1

\section{Percent}

$\begin{array}{cccc}1 & 2 & 3 & 4 \\ 0 & +2.2 & -8.3 & -2.2 \\ -2.2 & 0 & -2.1 & -6.3\end{array}$




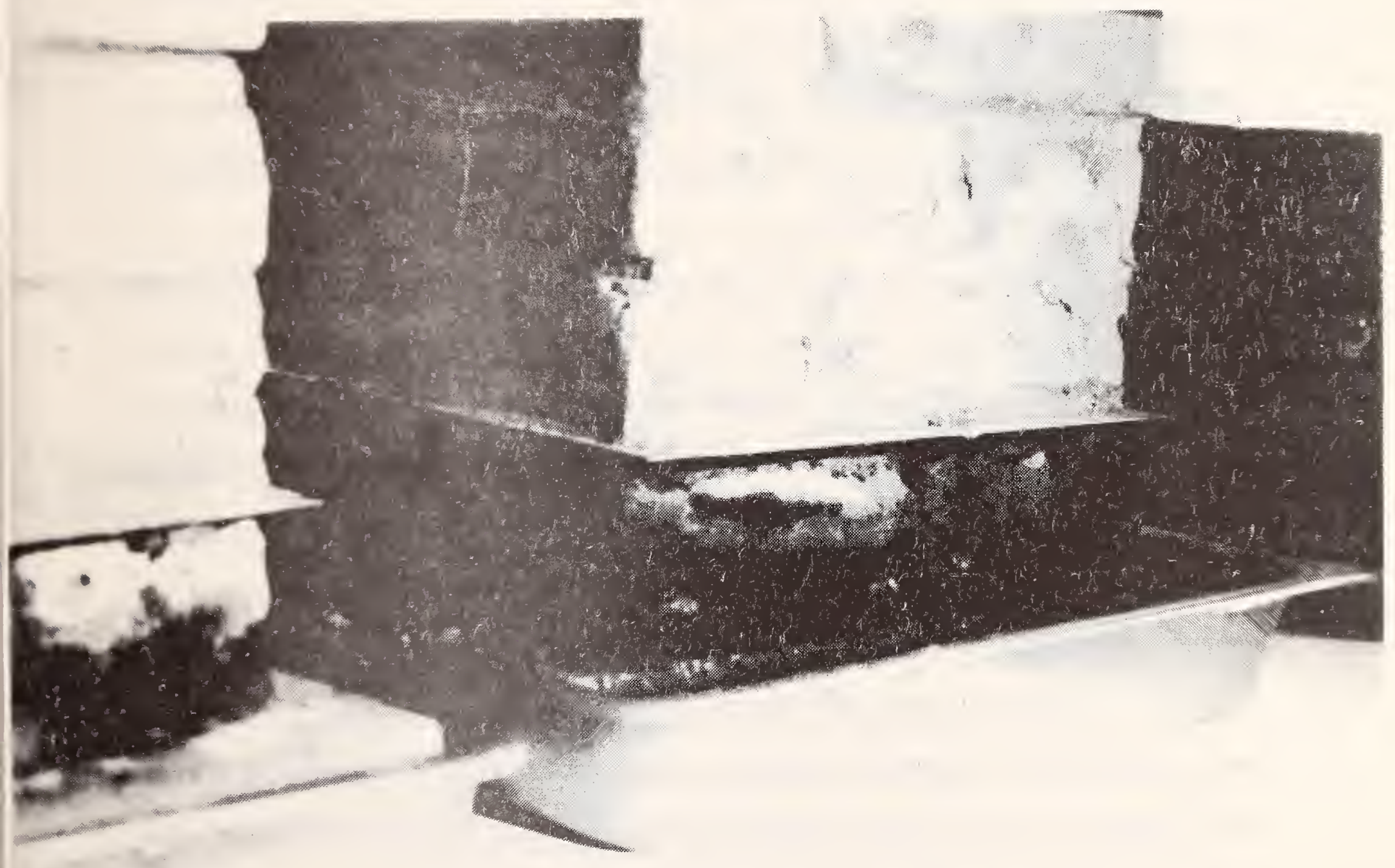

wh

Figure 5. Adobe Test Walls With Aluminum Membrane. 
Results of this study suggests that it is not feasible nor desirable to create an impervious damp course membrane in adobe walls by injecting a chemical grout. Two commonly used chemical grouts would not adequately penetrate the adobe tested in this study, when injected by normal pressure techniques. While the insertion of a metallic membrane can prevent the rise of ground water above it, water accumulating beneath the membrane could probably lead to the undercutting of the adobe wall and a reduction in its comprehensive strength.

Steen [12] suggested that in many cases adobe walls could be adequately protected from both ground water and rain water accumulating at the wall base, by the construction of drainage systems. He recommends the digging of trenches around adobe walls and filling them with gravel of sufficient size to prevent the rise of capillary water. However, if the ground water is constantly present at a high level, as in the case of the Tumacacori church [13], other solutions need to be identified.

The waterproofing of the foundation, if existing, or the underlying soil by chemical treatment could be at least as difficult as grouting adobe walls because of the large amounts of silt and clay present in many of the soils. It is the opinion of the authors that only by allowing a chemical grout to slowly infiltrate the pores of such soils is there any chance of success. Even though the chances for success may be low, this approach appears worthy of some evaluation using field test sites. The process may require several days, therefore, the chemical grout must have a long gel period. In addition, the work by Fenn [14] suggests that in general a water thinned system is preferred to an organic solvent thinned chemical grout. 
Haapala [15] has suggested that the foundations of old adobe walls can be upgraded by placing concrete footing walls along each side of the existing walls. Then the concrete walls can be waterproofed. However, the effects of excavating and the settling of the foundations on the adobe structure should be detemined before proceeding.

The above discussion has been concerned with possible methods for preventing the capillary rise of ground water in adobe walls. It is conceivable that in certain circumstances the rise of ground water should not be completely prevented. For example, soluble salts in adobe structures may only be harmful if the moisture content of the adobe is fluctuating sufficiently so that the salts are being dissolved and recrystallized or phase changes in their hydrates are occurring. Therefore, if adobe walls are heavily laden with soluble salts, their moisture contents possibly should be kept as constant as possible as long as the adobe walls have adequate mechanical properties. Further, if adobe walls have a high moisture content because of capillary water, severe drying shrinkage could take place if the migration of ground water is completely stopped. Clearly, further work needs to be performed to determine the effects of changing the moisture contents and patterns on the durability of adobe walls. 


\section{SUMMARY AND CONCLUSIONS}

The feasibility of creating impervious membranes in existing adobe walls by the injection of chemical grouts was investigated. For this purpose, the coefficients of permeability to water of Tumacacori soil, Tumacacori and Sand, and Escalante adobe were measured by the falling head method. Their permeability values were all less than $10^{-6} \mathrm{~cm} / \mathrm{sec}$. This is less than the water permeability valve of $10^{-5} \mathrm{~cm} / \mathrm{sec}$, which is usually taken as the lower limit for groutability. Calculations based on the analysis of the particle size distributions of these materials also indicated that there is little probability of successfully grouting them.

The grouting of adobe wall sections and individual bricks with two commonly used chemical grouts was attempted. Two application methods were investigated: (1) injection of the grout under pressure into adobe test walls; and (2) soaking test walls and brick in the liquid grouts. Neither method was successful in creating an impervious membrane in the test specimens.

The effects of inserting metallic damp course membranes on the durability existing adobe wall were also investigated. It was found that settling took place in the adobe walls below the membrane. In addition, efflorescence due to the migration of soluble salts to the surface of the walls was observed. Therefore, the results of this study suggests that it may not be feasible nor desirable to create an impervious damp course membrane in adobe walls whether by injecting a chemical grout or by the insertion of a metallic membrane. 
1. Clifton, J. R., Preservation of Historic Adobe Structures-A Status Report, NBS Technical Note 934, National Bureau of Standards (1977).

2. Torraca, G., An International Project for the Study of Mud-Brick Preservation in Conservation of Stone, New York Conference on Conservation of Stone and Wooden Objects, June 1970, pp. 47-57.

3. Clifton, J. R. and Davis, F. L., Mechanical Properties of Adobe, NBS Technical Note, National Bureau of Standards (in press).

4. Clifton, J. R., Brown, P. W., and Robbins, C. R., Methods for Characterizing Adobe Building Materials, NBS Technical Note 977 , National Bureau of Standards (1978).

5. Brown, P. W., Robbins, C. R., and Clifton, J. R., Factors Affecting the Durability of Adobe Structures, NBIR 78-1495, National Bureau of Standards (1978).

6. Standard Test Method for Compressive Strength of Hydraulic Cement Mortars (Using 2-in or 50-mm Cube Specimens), American Society for Testing and Materials (ASTM), Designation C109-73.

7. Herndon, $\mathrm{T}$. and Lenahan, T., Grouting in Soils. Volume 1. A State-of-the-Art Report (1976); available from National Technical Information Service, Catalog No. PB259043.

8. Herndon, J. and Lenahan, T., Grout in Soils. Volume 2. Design and Operations Manual (1976); available from the National Technical Information Service, Catalog No. PB259044.

9. Standard Method of Test for Permeability of Granular Soils (Constant Head), ASTM Designation D 2434-68.

10. AM-9 Chemical Grout, American Cyanamid Company (1965).

11. Abotomey, D. P., A New Load Bearing Mechanical Damp Course. Proceedings and International Symposium on the Deterioration of Building Stones (Athens, 1976).

12. Steen, C., An Archaeologist's Summary of Adobe, E1 Palacio, Vol. 77 (No. 4), pp. 29-38 (1971).

13. Crosby, A., Preliminary Report on the Preservation Project at Tumacacori National Monument, U.S. National Park Service (1977). 
14. Fenn, D. B., Second Annual Report. Chemical Stabilization of Prehistoric Structures at Chaco Canyon National Monument, U.S. National Park Service (1977).

15. Haapala, K.V., Stabilizing and Restoring 01d Adobe Structures in California, Newsletter of the National Association of Restoration Specialists (Murphy, California, June 1972). 
NBS. I14A (REV. 0-78)

\begin{tabular}{|c|c|c|}
\hline $\begin{array}{l}\text { U.S. OEPT. OF COMM. } \\
\text { BIBLIOGRAPHIC DATA } \\
\text { SHEET }\end{array}$ & $\begin{array}{l}\text { 1. PUBLICATION OR REPORT NO. } \\
\text { NBSIR } 79-1730\end{array}$ & 2, Gov? 2 Accession No. \\
\hline
\end{tabular}

4. TITLE AND SUBTITLE

Protecting Adobe Walls From Ground Water

5. Publication Date

March 1979

6. Performing Organization Code

8. Performing Organ. Report No.

James R. Clifton and Frankie L. Davis

9. PERFORMING ORGANIZATION NAME AND ADDRESS

NATIONAL BUREAU OF STANDARDS

DEPARTMENT OF COMMERCE

WASHINGTON, DC 20234

12. SPONSORING ORGANIZATION NAME AND COMPLETE ADDRESS (Street, City, State, zIP)

U.S. Department of Interior

National Park Service

Washington, D.C. 20240
10. Project/Task/Wonk Únit No.

11. Contract/Grant No.

13. Type of Report \& Period Covered

Fina1

14. Spensoring Agency Code

15. SUPPLEMENTARY NOTES

Document describes a computer program; SF-185, FIPS Software Summary, is attached.

16. ABSTRACT (A 200-word or less factual summary of most significant information. If document includes a significant bibliography or literature survey, mention it here.)

Two methods for creating impervious membranes in existing adobe walls were investigated. They were the injection of chemical grouts and installation of a metallic membrane. Chemical grouting was unsuccessful because of the low permeability of the tested adobe materials. The metallic membrane did prevent the migration of moisture in the adobe underneath the membrane, weakening the adobe. Further, soluble salts migrated to the surface of the wet adobe. Alternative methods for protecting adobe structures from ground water and moff water are discussed, including the installation of effective drainage systems and upgrading the foundations.

17. KEY WORDS (six to twelve entries; alphabetical order; capitalize only the first letter of the first key word unless a proper name; separated by semicolons)

Adobe building materials; chemical grouts; damp course membrane; metallic membrane; permeability; preservation technology.
18. AVAILABILITY
[X] Unlimited

For Official Distribution. Do Not Release to NTIS

Order From Sup. of Doc., U.S. Government Printing Office, Washington, DC 20402, SD Stock No. SNO03-003-

C Order From National Technical Information Service (NTIS), Springfield, VA. 22161

\begin{tabular}{|l|c|}
\hline $\begin{array}{l}\text { 19. SECURITY CLASS } \\
\text { (THIS REPORT) } \\
\text { UNCLASSIFIED }\end{array}$ & $\begin{array}{c}\text { 21. NO. OF } \\
\text { PRINTED PAGES }\end{array}$ \\
\hline $\begin{array}{l}\text { 20. SECURITY CLASS } \\
\text { (THIS PAGE) } \\
\text { UNCLASSIFIED }\end{array}$ & 28. Price \\
$\$ 4.50$
\end{tabular}



